\title{
Biological Monitoring of Occupational Exposure to Metals in Electric Steel Foundry Workers and Its Contribution to 8-Oxo-7,8-Dihydro-2'- Deoxyguanosine Levels
}

\author{
Laura Campo $^{1, *}$, Mariem Hanchi ${ }^{2}$, Sabrina Sucato ${ }^{3}$, Dario Consonni ${ }^{1}\left(0\right.$, Elisa Polledri ${ }^{3}{ }^{\circledR}$, \\ Luca Olgiati ${ }^{1}$, Dalila Saidane-Mosbahi ${ }^{2}$ and Silvia Fustinoni ${ }^{1,3}$ \\ 1 Fondazione IRCCS Ca' Granda Ospedale Maggiore Policlinico, 20122 Milan, Italy; \\ dario.consonni@policlinico.mi.it (D.C.); luca.olgiati@policlinico.mi.it (L.O.); silvia.fustinoni@unimi.it (S.F.) \\ 2 Laboratory of Analysis, Treatment and Recovery of Environmental Pollutants and Products, Faculty of \\ Pharmacy, 5000 Monastir, Tunisia; meriamhanchi@yahoo.fr (M.H.); dalila.saidane@fphm.rnu.tn (D.S.-M.) \\ 3 Department of Clinical Sciences and Community Health, Università degli Studi di Milano, 20122 Milan, \\ Italy; sabrina.sucato@unimi.it (S.S.); elisa.polledri@unimi.it (E.P.) \\ * Correspondence: laura.campo@policlinico.mi.it; Tel.: +39-02-50320116
}

Received: 31 January 2020; Accepted: 5 March 2020; Published: 11 March 2020

\begin{abstract}
In this study, the urinary concentrations of selected metals in workers from an electric steel foundry in Tunisia were assessed and compared with existing biological limit values and general population reference values. Moreover, the association between oxidative DNA damage, measured as urinary 8-oxo-7,8-dihydro-2' deoxyguanosine (8-oxodG) and co-exposure to metals and polycyclic aromatic hydrocarbons (PAHs) was evaluated. Urinary levels of 12 metals were determined by inductively coupled plasma-mass spectrometry (ICP-MS) in end-shift spot samples from 89 workers. The urinary levels of phenanthrene (U-PHE), as marker of exposure to PAHs, and 8-oxodG were also available. Median levels ranged from $0.4 \mu \mathrm{g} / \mathrm{L}$ (cobalt, Co, and thallium, Tl) to $895 \mu \mathrm{g} / \mathrm{L}$ (zinc, Zn). Only $1 \%$ of samples was above the biological limit values for $\mathrm{Co}$, and up to $13.5 \%$ of samples were above limit values for $\mathrm{Cd}$. From $3.4 \%$ (Co) to $72 \%$ (lead, $\mathrm{Pb}$ ) of samples were above the reference values for the general population. Multiple linear regression models, showed that manganese (Mn), $\mathrm{Zn}$, arsenic (As), barium (Ba), $\mathrm{Tl}$, and $\mathrm{Pb}$ were significant predictors of 8-oxodG $(0.012 \leq p \leq 0.048)$; $\mathrm{U}-\mathrm{PHE}$ was also a significant predictor $(0.003 \leq p \leq 0.059)$. The variance explained by models was low $(0.11 \leq$ $\left.\mathrm{R}^{2} \leq 0.17, p<0.005\right)$, showing that metals and PAHs were minor contributors to 8-oxodG. Overall, the comparison with biological limit values showed that the study subjects were occupationally exposed to metals, with levels exceeding biological limit values only for $\mathrm{Cd}$.
\end{abstract}

Keywords: electric steel foundry; metals; urine; biological monitoring; occupational exposure; biological limit values; 8-oxo-7,8-dihydro-2'-deoxyguanosine; polycyclic aromatic hydrocarbons

\section{Introduction}

The production of steel by recycling scrap using an electric arc furnace is a commonly used process. In Europe, it accounts for $41.8 \%$ of the total steel production [1]. The main processing operations of a typical steel foundry are scrap handling, metal melting, mold and core production, casting, and finishing. During the manufacturing process, steel foundry workers are potentially exposed to metal fumes (in particular $\mathrm{Cr}, \mathrm{Mn}, \mathrm{Ni}$, and $\mathrm{Cd}$ ), polycyclic aromatic hydrocarbons (PAHs), and other pollutants such as silica and quartz dust, and binder compounds (formaldehyde, resins, and oils) [2]. Metal fumes are formed by evaporation, condensation and oxidation of metals in air. Furnace tenders, 
smelters, casters, ladle-men, pourers and crane drivers are exposed to fumes from molten metal; fettlers are exposed to metal fumes and dusts from grinding, welding and flame-cutting operations. On the other side, PAHs mainly result from thermal decomposition of carbonaceous ingredients in foundry sand. Moreover, another source of PAHs is exhaust gases from engines, furnaces, and ovens [2].

Several cohort studies have shown an increased incidence of lung cancer [3] and bladder cancer [4] among steel foundry workers. Based on epidemiological evidences, the International Agency for Research on Cancer has classified the occupational exposure during iron and steel founding as carcinogenic to humans (Group 1) [2].

Data about metal emissions in air during steel production in the European Union, show that $\mathrm{Zn}$ is the metal with the highest emissions with levels up to $24,000 \mathrm{mg} / \mathrm{t}$ of liquid steel, followed by As (up to $14,000 \mathrm{mg} / \mathrm{t}$ ), $\mathrm{Pb}$, chromium (Cr), and nickel (Ni) (up to $2800 \mathrm{mg} / \mathrm{t}$ ), copper (Cu) (up to $510 \mathrm{mg} / \mathrm{t}$ ), and $\mathrm{Cd}$ (up to $148 \mathrm{mg} / \mathrm{t}$ ) [1]. A study in Italy reported that iron was the principal constituent $(78 \%$ ) of the dust released as fine and ultrafine particulate matter through diffuse emissions by an electric steel foundry, followed by aluminum (Al), Zn, and Mn (5-7\%), while other metals contributed less than $1 \%[5]$.

Only a few studies report personal or environmental exposure to metals in steel workers. The median personal concentration of respirable dust in an integrated-cycle steel foundry in Italy was below $0.1 \mu \mathrm{g} / \mathrm{m}^{3}$ for $\mathrm{As}$ and $\mathrm{Cd},<2 \mu \mathrm{g} / \mathrm{m}^{3}$ for $\mathrm{Cr}, \mathrm{Ni}, \mathrm{Cu}$, and $\mathrm{Pb}$, and $7.3 \mu \mathrm{g} / \mathrm{m}^{3}$ for $\mathrm{Mn}[6]$. In four nonferrous metal foundries in Brazil, environmental levels were up to $200 \mu \mathrm{g} / \mathrm{m}^{3}$ for Pb, up to $8 \mu \mathrm{g} / \mathrm{m}^{3}$ for $\mathrm{Cd}$, up to $4.5 \mu \mathrm{g} / \mathrm{m}^{3}$ for $\mathrm{Ni}$, and up to $1.6 \mu \mathrm{g} / \mathrm{m}^{3}$ for $\mathrm{Mn}$ [7]. The high variability of metal emission observed between foundries may originate from differences in the production process, input materials, type of steel produced, and plant characteristics.

While environmental monitoring is a useful tool to collect information about the metal concentration in the ambient air of a working place, biological monitoring provides an information about the internal dose of individuals, taking into account the intra-individual variability. The biological monitoring of metal exposure in steel workers has been very limited, with $\mathrm{Ni}$, and $\mathrm{Cd}$ as the most investigated metals [6-13].

The exposure to metals is associated with toxic effects; various studies reported adverse health effects including neurotoxicity following exposure to $\mathrm{As}, \mathrm{Pb}$, and $\mathrm{Mn}$ [14], the development of cardiovascular diseases following exposure to $\mathrm{Pb}, \mathrm{Cd}$, and $\mathrm{As}$ [15], and other effects as kidney damage, endocrine disruption, and immunological effects [16]. Moreover, some metals such as $\mathrm{As}, \mathrm{Cd}, \mathrm{Ni}$, and $\mathrm{Cr}$ (VI) are classified as carcinogenic to humans [2].

Metals, as well as PAHs, enhance oxidative stress by the generation of reactive oxygen species by various mechanisms. Oxygen free radicals can induce a variety of damage to DNA, such as the hydroxyl radical that binds DNA in the eight position of the guanine leading to its modification. The resulting 8-oxo-7,8-dihydro-2'-deoxyguanosine (8-oxodG) is considered a pre-mutagenic lesion and a biomarker of DNA oxidation $[17,18]$.

In our previous study, we evaluated the exposure to PAHs in Tunisian electric steel foundry workers by measuring urinary level of 16 unmetabolized PAHs (U-PAHs), and eight hydroxylated metabolites of PAHs $[19,20]$. The analysis of a large panel of biomarkers allowed us to propose urinary unmetabolized phenanthrene (U-PHE) and 1-hydroxyphenanthrene as the most suitable biomarkers of PAH exposure [20]. In a successive work in the same population, we found a small, but significant contribution of urinary PAHs, particularly U-PHE, on 8-oxodG excretion [19].

In this study, we evaluated the exposure to metals in the same workers, by measuring a panel of 12 urinary metals (vanadium $\mathrm{V}, \mathrm{Cr}, \mathrm{Mn}, \mathrm{Co}, \mathrm{Ni}, \mathrm{Cu}, \mathrm{Zn}$, total $\mathrm{As}, \mathrm{Cd}, \mathrm{Ba}, \mathrm{Tl}$, and $\mathrm{Pb}$ ) and by comparing metal levels with existing biological limit values proposed by some international agencies and general population reference values. Moreover, the association between co-exposure to metals and PAHs on 8-oxodG excretion was investigated. 


\section{Materials and Methods}

\subsection{Subjects and Urine Collection}

The sampling took place in August 2013 at an electric steel foundry in Tunisia previously described [20]. A self-administered questionnaire was used to obtain subject's personal information, including personal characteristics, smoking habits, and job title.

Workers were classified into six groups based on their job title and workshop (department): (1) steel smelters workers (SSW, N = 30), operating in the steel smelting workshop in which scrap and ferrous alloys are first melted by an electric arc furnace (EAF), and then conducted to a continuous casting process in the same area; main job tasks are smelters, molders, and casters. (2) Rolling mills $(\mathrm{N}=34)$ and cable fiber workers $(\mathrm{N}=2)(\mathrm{RM}-\mathrm{CF}, \mathrm{N}=36)$, operating in the rolling mill workshop where metal is heated and then passed in a forming process to give it the final shape, in particular cable fiber workers produce fine cables by heating the rolled product; main job tasks are rolling-mill operators, and machine operators. (3) Galvanization workers (GALV, $N=7$ ), operating in the galvanization workshop, where the products are immersed in a hot zinc bath to coat the steel and prevent it from rusting. (4) Engine maintenance workers (MAN, $N=12$ ), repairing and maintaining engines using mainly welding and flame-cutting operations. (5) Measure and quality control workers $(Q C, N=4)$, operating in a separate department where adequate quality of products is assessed by measuring, examining, and testing the characteristics of the products. (6) Individuals (ADM, N =4,) with job tasks non involving direct contact with metals (security, material transport inside the factory, and administrative job tasks).

Urine spot samples from each subject were collected at the end of an 8-h work shift. Samples were blind coded, shipped to the laboratory in dry ice, and frozen at $-20^{\circ} \mathrm{C}$ until analyses. All participants gave their informed consent about their inclusion in the study. The study was approved by the ethics commission of the University of Medicine of Monastir (Tunisia).

\subsection{Measurement of Urinary Metals}

Before analysis, urine samples were thawed at room temperature for $2 \mathrm{~h}$. Each sample was mixed and heated at $37^{\circ} \mathrm{C}$ for $30 \mathrm{~min}$ to dissolve the sediment. An aliquot of $600 \mu \mathrm{L}$ of urine was transferred into a $10 \mathrm{~mL}$ polyethylene tube and added with $2.4 \mathrm{~mL}$ of nitric acid $0.05 \% v / v$, prepared by dilution of ultrapure nitric acid (69\% TraceSelect, Fluka, France), and containing 45Sc, 89Y, and 111In at a concentration of $7.5 \mu \mathrm{g} / \mathrm{L}$ as internal standards (Inorganic Ventures, Inc., Lakewood, NJ, USA). All solutions were prepared using Milli- ${ }^{\circledR}$ ultrapure water (conductivity $0.056 \mu \mathrm{S} / \mathrm{cm}$ ) (Merck, Darmstadt, Germany).

Samples were analyzed by an inductively coupled plasma-mass spectrometer (ICP-MS) X Series II (Thermo Electron Corporation, Rodano, Italy) equipped with standard nickel cones, torch, and quartz impact bean spray chamber and interfaced to an auto sampler ASX-100 (Teledyne CETAC Technologies, Omaha, NE, USA). The instrument was operated with standard mode for $\mathrm{Pb}, \mathrm{Zn}, \mathrm{Ba}, \mathrm{Tl}$, and $\mathrm{Cd}$ and collision cell mode (CCT-Ked) for $\mathrm{Mn}, \mathrm{Ni}, \mathrm{Cu}, \mathrm{V}, \mathrm{As}, \mathrm{Co}$, and $\mathrm{Cr}$. The typical standard mode conditions were as follows: extraction voltage $-100 \mathrm{~V}$, focus voltage $8.5 \mathrm{~V}$, nebulizer gas flow rate $0.90 \mathrm{~L} / \mathrm{min}$ and dwell time $50 \mathrm{~ms}$ for each element. For each sample, three replicates were run. In CCT-Ked, a cell gas flow of $3.5 \mathrm{~mL} / \mathrm{min}$ of $8 \% v / v$ hydrogen in helium was used to reduce interferences.

Before each analytical sequence, the instrument was calibrated using the tune solution obtained by dilution 1:50 of the multi-element solution Tune A (containing Ba, Be, Ce, Co, $\mathrm{In}, \mathrm{Li}, \mathrm{Ni}, \mathrm{Pb}$, each at $10 \mathrm{mg} / \mathrm{mL}$ in $5 \% \mathrm{HNO}_{3}$ ) (Analytika, Prague, Czech Republic).

The calibration curves were in the range $0.1-50 \mu \mathrm{g} / \mathrm{L}$ for all analytes, but $\mathrm{Zn}$, for which a calibration curve in the range $50-1000 \mu \mathrm{g} / \mathrm{L}$ was used. The calibration solutions were obtained by dilution of the multi-element standard stock solution 71A, containing all elements analyzed at $10 \mathrm{mg} / \mathrm{mL}$ (Inorganic Ventures, Inc., Lakewood, NJ, USA), with nitric acid 0.05\% $v / v$ containing 45Sc, 89Y, 111In, at $7.5 \mu \mathrm{g} / \mathrm{L}$ as internal standards. The calibration curves for each metal were linear with correlation coefficient 
$\geq 0.999$. The limits of quantification (LOQs), calculated as ten times the standard deviation of the blank signal, were as follows: V 0.02, Cr 0.05, Mn 0.06, Co 0.02, Ni 0.18, Cu 0.03, Zn 0.71, As 0.5, Cd 0.03, Ba $0.03, \mathrm{Tl} 0.02$, and $\mathrm{Pb} 0.07 \mu \mathrm{g} / \mathrm{L}$. Internal quality assurance was performed using two quality controls (QCs) for metals in urine: Lyphocheck Urine Metals Control, Level-1 (Bio-Rad Laboratories, USA), and Seronorm ${ }^{\circledR}$ Level-1 (Sero AS, Billingstad, Norway). Before analysis, these controls were reconstituted according to the manufacturer's instruction. For quality controls, precision, as the variation coefficient, was $<10 \%$ and the accuracy was $85-115 \%$ of the theoretical values.

\subsection{Measurement of U-PHE, 8-oxodG and Cotinine}

The U-PHE was analyzed, together with other 15 U-PAHs, by solid phase microextraction coupled with gas chromatography-triple quadrupole tandem mass spectrometry, as previously described [20,21].

Urinary 8-oxodG and urinary cotinine (U-COT) were analyzed simultaneously by liquid chromatography coupled with triple quadrupole mass spectrometry, as previously described $[19,22]$. U-COT was measured to characterize each subject's smoking status. Subjects with U-COT $\geq 30 \mu \mathrm{g} / \mathrm{L}$ were classified as smokers [23].

Creatinine (cr) was determined photometrically as picrate using Jaffe's colorimetric method [24].

\subsection{Statistical Analysis}

Statistical analyses were carried out using the SPSS package for Windows (version 25.0; SPSS Statistics, IBM, Italy) and the Stata 13 package (version 2013; Stata Corp LP, College Station, TX, USA). A value corresponding to one-half of the quantification limit was assigned to measurements below analytical quantification. Data on urinary biomarkers were decimal log-transformed to ensure normal distribution. Student's $t$-test was applied to compare two independent groups (i.e., smokers vs. nonsmokers), analysis of variance (ANOVA) with Bonferroni correction was applied to compare more than two independent groups (i.e., job titles). Pearson's correlations were used to measure the associations between quantitative variables.

Multiple linear regression models were used to evaluate the effect of smoking status ( $\log _{10}$ U-COT, $\mu \mathrm{g} / \mathrm{L})$, urinary creatinine $\left(\log _{10}, \mathrm{~g} / \mathrm{L}\right)$, age (years), and body mass index $\left(\mathrm{BMI}, \mathrm{kg} / \mathrm{m}^{2}\right)$ as independent variables on the urinary levels of each metal $\left(\log _{10}\right.$ metal, $\left.\mu \mathrm{g} / \mathrm{L}\right)($ dependent variable). The final model was:

$$
\text { Urinary metal }=\text { intercept }+\beta 1 \times \text { U-COT }+\beta 2 \times \text { creatinine }+\beta 3 \times \text { age }+\beta 4 \times \text { BMI }
$$

Two different multiple linear regression models, Model A and Model B, were used to study the association between urinary 8-oxodG (dependent variable), and metal doses or metal and PAH co-exposure (independent variables). Model A evaluated the effect of the urinary level of each metal $\left(\log _{10}\right.$ metal, $\left.\mu \mathrm{g} / \mathrm{L}\right)$, smoking status $\left(\log _{10} \mathrm{U}-\mathrm{COT}, \mu \mathrm{g} / \mathrm{L}\right)$, urinary creatinine $\left(\log _{10}, \mathrm{~g} / \mathrm{L}\right)$, age (years), and BMI $\left(\mathrm{kg} / \mathrm{m}^{2}\right)$ on the 8 -oxodG levels $\left(\log _{10}, \mu \mathrm{g} / \mathrm{L}\right)$. Each regression analysis was run separately for each metal. The final model A was:

$$
\text { 8-oxodG }=\text { intercept }+\beta 1 \times \text { urinary metal }+\beta 2 \times \text { creatinine }+\beta 3 \times \text { U-COT }+\beta 4 \times \text { age }+\beta 5 \times \text { BMI }
$$

Model B evaluated the effect of the urinary level of each metal $\left(\log _{10}\right.$ metal, $\left.\mu \mathrm{g} / \mathrm{L}\right)$, PAH exposure $\left(\log _{10}\right.$ U-PHE ng/L), smoking status $\left(\log _{10} \mathrm{U}-\mathrm{COT}, \mu \mathrm{g} / \mathrm{L}\right)$, urinary creatinine $\left(\log _{10}, \mathrm{~g} / \mathrm{L}\right)$, age (years), and BMI $\left(\mathrm{kg} / \mathrm{m}^{2}\right)$ on the 8-oxodG levels $\left(\log _{10}, \mu \mathrm{g} / \mathrm{L}\right)$. Each regression analysis was run separately for each metal and U-PHE together. The final Model B was:

$$
\begin{gathered}
8 \text {-oxodG }=\text { intercept }+\beta 1 \times \text { urinary metal }+\beta 2 \times \mathrm{U} \text {-PHE }+\beta 3 \times \text { creatinine }+\beta 4 \times \\
\mathrm{U} \text {-COT }+\beta 5 \times \text { age }+\beta 6 \times \text { BMI }
\end{gathered}
$$


For each model, the regression slopes of the resulting linear equations were anti-log10 converted to obtain the geometric mean ratio $(\mathrm{GMR})$. The $(\mathrm{GMR}-1) \times 100$ gives the percentage increase or decrease of 8-oxodG for each 10-fold increase of each urinary metal or U-PHE concentration.

\section{Results}

\subsection{Study Population}

Main characteristics of the study population were previously reported [20]. Of the 93 male workers participating to the study, urine samples for metal analysis were available for 89 individuals. In these subjects, age ranged from 25 to 59 years (mean 47 years) and BMI ranged from 20 to 34 (mean $27 \mathrm{~kg} / \mathrm{m}^{2}$ ). Based on U-COT excretion, 51 (57\%) subjects were classified as smokers.

\subsection{Urinary Metal Levels}

Table 1 shows the results of metal analyses and statistical comparisons among job titles. Results are shown for all workers and for workers stratified by job titles. In all subjects, median levels ranged from $0.4 \mu \mathrm{g} / \mathrm{L}$ (Co and Tl) to $895 \mu \mathrm{g} / \mathrm{L}$ (Zn) (Table 1). All metals were above the LOQ in all samples, but one sample for $\mathrm{Cd}$.

Median levels were significantly $(p<0.05)$ or marginally different $(0.05<p<0.1)$ among job titles for all metals, except $\mathrm{Cr}$ and $\mathrm{Mn}$. In particular, the SSW group had the lowest levels of Co, Cu, Zn, As, $\mathrm{Cd}, \mathrm{Ba}, \mathrm{Tl}$, and $\mathrm{Pb}$ in comparison with the other groups. On the contrary, no significant differences were found among the other job titles (Table 1).

Median levels were significantly different between smokers and non-smokers only for V ( 0.88 vs. $0.59 \mu \mathrm{g} / \mathrm{L}$ in non-smokers and smokers, $p=0.001)$ and $\mathrm{Tl}(0.3$ vs. $0.4 \mu \mathrm{g} / \mathrm{L}$ in non-smokers and smokers, $p=0.022)$.

Urinary metals were generally correlated within each other's: partial Pearson's r correlation, when significant, ranged from 0.218 (As vs. $\mathrm{Cr}, p=0.040$ ) to 0.850 . The highest correlations were found for Cd vs. $\mathrm{Pb}(\mathrm{r}=0.850, p<0.0001)$, Cd vs. $\mathrm{Tl}(\mathrm{r}=0.838, p<0.001)$, and Tl vs. $\mathrm{Pb}(\mathrm{r}=0.836, p<0.001)$ (data not shown).

\subsection{U-PHE and 8-oxodG Levels}

The results of the analysis of U-PHE, together with the analysis of other U-PAHs and hydroxylated metabolites, and the results of the analysis of 8-oxodG were previously reported $[19,20]$ and here are only summarized. Briefly, in all subjects, U-PHE median level (5th-95th percentile) was 18.9 (7.1-74.5) ng/L, while 8-oxodG median level (5th-95th percentile) was $3.19(0.84-14.94) \mu \mathrm{g} / \mathrm{L}$ [1.85 (0.46-9.05) $\mu \mathrm{g} / \mathrm{g}$ creatinine].

\subsection{Correlations between Urinary Metals, U-PHE, and 8-oxodG}

Significant, or marginally significant, linear correlations were found between 8-oxodG and the following metals: $\mathrm{Mn}(\mathrm{r}=0.354, p=0.001), \mathrm{Tl}(\mathrm{r}=0.321, p=0.002), \mathrm{Zn}(\mathrm{r}=0.309, p=0.003)$, As $(\mathrm{r}=$ $0.309, p=0.003), \mathrm{Pb}(\mathrm{r}=0.283, p=0.007), \mathrm{Co}(\mathrm{r}=0.239, p=0.024), \mathrm{Ba}(\mathrm{r}=0.213, p=0.045), \mathrm{Cr}(\mathrm{r}=0.213$, $p=0.045)$, and Cd $(\mathrm{r}=0.194, p=0.071)$.

Significant correlations were found between U-PHE and some metals, specifically Mn $(r=0.454$, $p \leq 0.001)$, and $\mathrm{Zn}(\mathrm{r}=0.225, p=0.034)$.

A significant linear correlation between U-PHE and 8-oxodG was found $(\mathrm{r}=0.327, p<0.001)$ [18]. 
Table 1. Urinary metal levels in all study subjects and in subjects stratified by job titles. Median $\left(5^{\text {th }}-95^{\text {th }}\right)$ is shown for each metal. The results of the statistical comparison among job title is also reported.

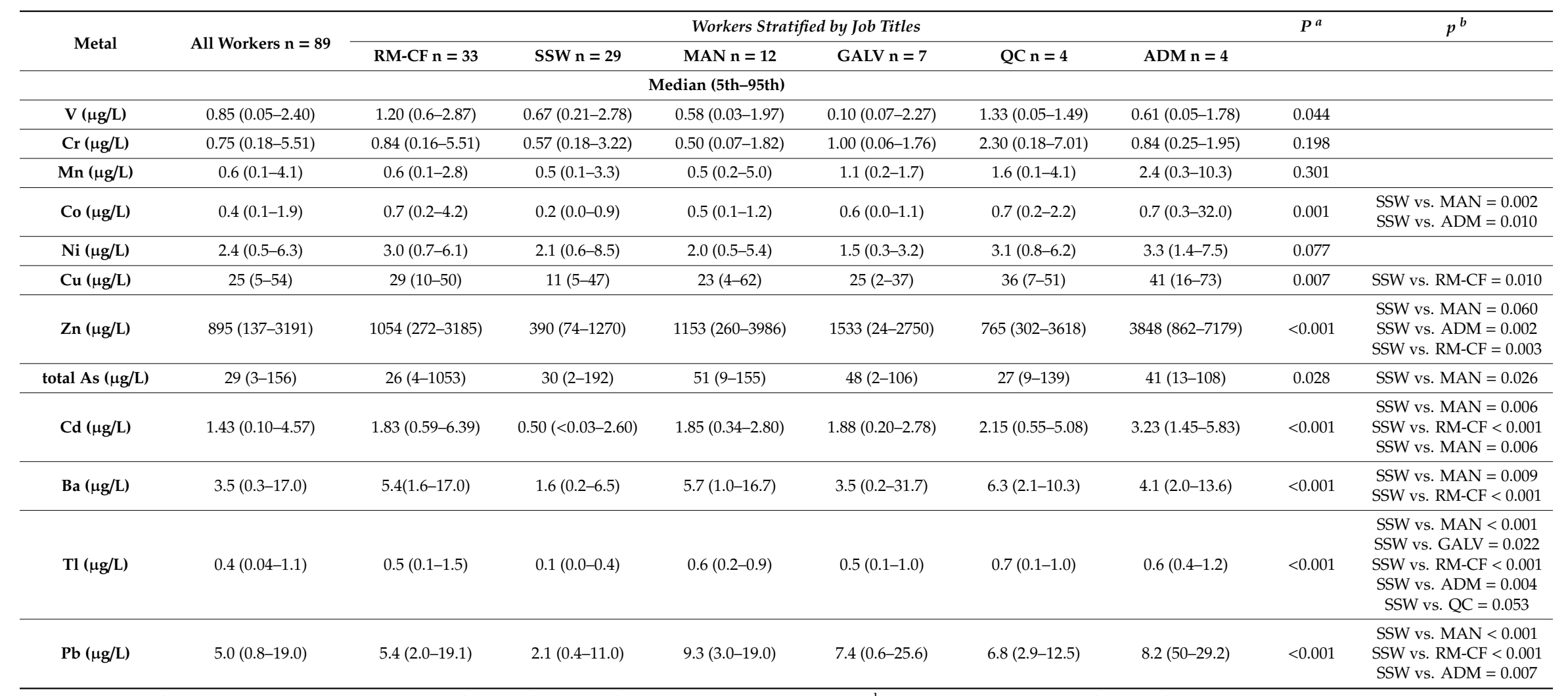

$\mathrm{n}=$ number of samples; $^{\mathrm{a}}=p$ values represent significance of ANOVA for comparison among job titles; ${ }^{\mathrm{b}}=p$ values represent significance of ANOVA post hoc multiple comparison with Bonferroni correction (only $p$ values $\leq 0.1$ are shown) 


\subsection{Multiple Regression Analysis}

The multiple linear regression model predicting urinary metals as a function of age, BMI, smoking habit, and creatinine showed that most metals were significantly associated with age $(\mathrm{Co}, \mathrm{Cu}, \mathrm{Zn}, \mathrm{As}$, $\mathrm{Cd}, \mathrm{Tl}$, and $\mathrm{Pb}, 0.001<p \leq 0.042)$ and creatinine ( $\mathrm{Cr}, \mathrm{Mn}, \mathrm{Co}, \mathrm{Ni}, \mathrm{Cu}, \mathrm{Zn}, \mathrm{As}, \mathrm{Tl}$, and $\mathrm{Pb}, 0.003<p \leq$ 0.075), while smoking habit and BMI were never significant predictive factors.

Table 2 shows the results of multiple regression analyses (Model A and Model B). In model $\mathrm{A}$, studying the association between 8-oxodG and the exposure to each metal, the coefficient of determination $\left(R^{2}\right)$ ranged from 0.03 for the model with Ni as independent variable, to 0.12 for the model with $\mathrm{Mn}$ as independent variable $(0.007 \leq p \leq 0.162)$ (Table 2$) . \mathrm{Mn}, \mathrm{Zn}, \mathrm{As}, \mathrm{Tl}$, and $\mathrm{Pb}$ were significant predictors of 8-oxodG $(0.003 \leq p \leq 0.027)$, while Co and Ba were marginally associated to 8 -oxodG $(0.05 \leq p \leq 0.10)$. The calculated increase of 8 -oxodG excretion ranged from $41 \%$ (Ba) to $88 \%$ $(\mathrm{Mn})$ for each 10 -fold increase of the metal excretion.

Table 2. Results of multiple linear regression analyses for predicting urinary levels of 8-oxodG as a function of metal exposure only (Model A) and as a function of co-exposure to metal and polycyclic aromatic hydrocarbons (PAHs), (Model B). Independent variables were the urinary levels of each single urinary metal in Model A, and the urinary levels of each single urinary metal plus urinary phenanthrene (U-PHE) in Model B.

\begin{tabular}{|c|c|c|c|c|c|}
\hline \multicolumn{3}{|c|}{ Model A } & \multicolumn{3}{|c|}{ Model B } \\
\hline $\begin{array}{l}\text { Independent } \\
\text { Variables }\end{array}$ & GMR (95\% CI); $p$ Value ${ }^{a}$ & $\mathbf{R}^{2}{ }_{a j j}^{b} ; P^{c}$ & $\begin{array}{l}\text { Independent } \\
\text { Variables }\end{array}$ & $\begin{array}{c}\text { GMR }(95 \% \text { CI }) \\
p \text { Value }^{\mathrm{a}}\end{array}$ & $\mathbf{R}^{2}{ }_{\text {adj }}{ }^{b} ; P^{c}$ \\
\hline \multirow{2}{*}{$\mathbf{V}$} & \multirow{2}{*}{$0.82(0.58-1.18) ; 0.282$} & \multirow{2}{*}{$0.04 ; 0.155$} & $\mathbf{V}$ & $0.87(0.62-1.23) ; 0.430$ & \multirow{2}{*}{$0.11 ; 0.017$} \\
\hline & & & U-PHE & $2.42(1.28-4.58) ; 0.007$ & \\
\hline \multirow{2}{*}{$\mathrm{Cr}$} & \multirow{2}{*}{$1.44(0.93-2.21) ; 0.100$} & \multirow{2}{*}{$0.05 ; 0.087$} & $\mathrm{Cr}$ & $1.40(0.46-2.13) ; 0.110$ & \multirow{2}{*}{$0.13 ; 0.008$} \\
\hline & & & U-PHE & $2.44(1.30-4.57) ; 0.006$ & \\
\hline \multirow{2}{*}{ Mn } & \multirow{2}{*}{1.88 (1.25-2.85); 0.003} & \multirow{2}{*}{$0.12 ; 0.007$} & Mn & $1.61(1.04-2.50) ; 0.033$ & \multirow{2}{*}{$0.15 ; 0.004$} \\
\hline & & & U-PHE & $1.90(0.97-3.70) ; 0.059$ & \\
\hline \multirow{2}{*}{ Co } & \multirow{2}{*}{$1.45(0.95-2.21) ; 0.085$} & \multirow{2}{*}{$0.06 ; 0.079$} & Co & $1.37(0.91-2.07) ; 0.128$ & \multirow{2}{*}{$0.13 ; 0.009$} \\
\hline & & & U-PHE & 2.38 (1.27-4.47); 0.008 & \\
\hline \multirow{2}{*}{$\mathrm{Ni}$} & \multirow{2}{*}{$1.36(0.75-2.43) ; 0.306$} & \multirow{2}{*}{$0.03 ; 0.162$} & $\mathrm{Ni}$ & $1.31(0.74-2.30) ; 0.348$ & \multirow{2}{*}{$0.11 ; 0.016$} \\
\hline & & & U-PHE & $2.46(1.30-4.63) ; 0.006$ & \\
\hline \multirow{2}{*}{$\mathrm{Cu}$} & \multirow{2}{*}{$1.41(0.80-2.49) ; 0.234$} & \multirow{2}{*}{$0.04 ; 0.141$} & $\mathrm{Cu}$ & $1.32(1.32-2.28) ; 0.323$ & \multirow{2}{*}{$0.11 ; 0.015$} \\
\hline & & & U-PHE & $2.42(1.28-4.57) ; 0.007$ & \\
\hline \multirow{2}{*}{ Zn } & \multirow{2}{*}{1.79 (1.16-2.75); 0.009} & \multirow{2}{*}{$0.10 ; 0.017$} & Zn & $1.61(1.05-2.48) ; 0.029$ & \multirow{2}{*}{$0.15 ; 0.003$} \\
\hline & & & U-PHE & $2.17(1.16-4.08) ; 0.016$ & \\
\hline \multirow{2}{*}{ total As } & \multirow{2}{*}{$1.52(1.08-2.13) ; 0.016$} & \multirow{2}{*}{$0.09 ; 0.025$} & As & $1.47(1.84-2.04) ; 0.021$ & $0.16: 0.003$ \\
\hline & & & U-PHE & $2.36(1.28-4.38) ; 0.007$ & $0.10,0.000$ \\
\hline $\mathrm{Cd}$ & $1.38(0.92-2.07) ; 0.114$ & $0.06: 0.080$ & $\mathrm{Cd}$ & 1.36 (1.84-2.04); 0.121 & $0.12 ; 0.010$ \\
\hline & & & U-PHE & $2.35(1.28-4.38) ; 0.009$ & \\
\hline Ва & $1.41(0.96-2.07) ; 0.081$ & $0.06: 0.077$ & Ba & 1.45 (1.00-2.09); 0.048 & $0.14: 0.005$ \\
\hline & & & U-PHE & $2.58(1.38-4.80) ; 0.003$ & \\
\hline $\mathrm{Tl}$ & $1.82(1.17-2.84): 0.008$ & $0.10 \cdot 0.016$ & $\mathrm{Tl}$ & 1.74 (1.13-2.67); 0.012 & $0.17: 0.002$ \\
\hline 11 & & & U-PHE & $2.33(1.26-4.31) ; 0.008$ & \\
\hline $\mathrm{Pb}$ & 1.73 (1.07-2.81); 0.027 & $0.08 ; 0.037$ & $\mathrm{~Pb}$ & $1.62(1.01-2.59) ; 0.046$ & $0.14 ; 0.004$ \\
\hline & & & U-PHE & $2.32(1.24-4.34) ; 0.009$ & \\
\hline
\end{tabular}

GMR $=$ geometric mean ratio. ${ }^{\mathrm{a}}=p$ values represent significance of each predictive variable. ${ }^{\mathrm{b}}=R^{2}$ adj values represent the adjusted coefficient of determination for the linear regression model. ${ }^{c}=P$ values represent the significance of the linear regression model.

In Model B, studying the association between 8-oxodG and the co-exposure to each metal and PAHs, the coefficient of determination $\left(\mathrm{R}^{2}\right)$ ranged from 0.11 for the models with $\mathrm{V}$, Ni or $\mathrm{Cu}$ and U-PHE as independent variables, to 0.17 for the model with $\mathrm{Tl}$ and U-PHE as independent variables $(0.002 \leq p$ 
$\leq 0.017$ ) (Table 2). Mn, Zn, As, Ba, Tl, and Pb were significant predictors of 8 -oxodG $(0.012 \leq p \leq 0.048)$. The calculated increase of 8 -oxodG excretion ranged from $45 \%$ (Ba) to $74 \%$ (Tl) for each 10 -fold increase in metal excretion. U-PHE was always a significant predictor of 8-oxodG $(0.003 \leq p \leq 0.059)$, with increases in the $90 \%-158 \%$ range for each 10 -fold increase in U-PHE excretion.

Creatinine, U-COT, age, and BMI were not significant predictive factors of 8-oxdG in any models (results not shown).

\section{Discussion}

In this paper, metal exposure in Tunisian steel foundry workers was assessed by measuring 12 urinary metals and by comparing metal levels with existing occupational limit values and general population reference values. Moreover, the role of the exposure to metals in determining an oxidative stress status was investigated, also in relationship with PAH co-exposure. As far as we know, this is the first time that the occupational exposure to metals has been evaluated by measuring a wide range of urinary metals in Tunisia.

With the aim of protecting workers' health, reference values for the biological monitoring of occupational exposure were proposed by some international agencies (summarized in Table 3). For the urinary metals here studied, the American Conference of Governmental Industrial Hygienists (ACGIH) recommends a biological exposure index (BEI) for $\mathrm{Cr}, \mathrm{Co}$, and $\mathrm{Cd}$ [25]. The Commission for the Investigation of Health Hazards of Chemical Compounds in the Work Area, MAK Commission (issued from the German Research Association DFG-Deutsche Forschung Gemeinschaft), provides exposure equivalents for carcinogenic substances (EKA) for $\mathrm{V}, \mathrm{Co}$, and $\mathrm{Ni}$, a biological guidance value (BLW) for $\mathrm{Co}$, and biological reference values for workplace substances (BAR) for $\mathrm{Cr}, \mathrm{Co}, \mathrm{Ni}, \mathrm{Cd}$, and $\mathrm{Ba}$ [26]. It is worth underlining that the EKA values are "exposure equivalents", that is the concentrations of a substance or its metabolites in biological material which is known to correspond to the concentration of the substance in the workplace air. From these relationships, the body burden which results from uptake of the substance exclusively by inhalation may be determined. So, the biological value is given together with the corresponding air level [26]. The Risk Assessment Committee (RAC) of the European Chemicals Agency (ECHA) provides a biological limit values (BLV) for Cd [27] (Table 3).

In comparison with these indexes, one sample for Co was above the ACGIH BEI and above the $30 \mu \mathrm{g} / \mathrm{L}$ DFG EKA (corresponding to an environmental exposure above $0.050 \mathrm{mg} / \mathrm{m}^{3}$ ) but below the DFG BLW value. For Cd, $3.4 \%$ and $13.5 \%$ of samples were above the ACGIH BEI and the ECHA BLV, respectively. ECHA has provided a limit value lower than ACGIH (2 vs. $5 \mu \mathrm{g} / \mathrm{g}$ creatinine) and it has classified this metal as a carcinogen Group C, that is a genotoxic carcinogen for which a mode of action-based threshold can be identified and a health-based OEL is proposed [28]. No sample was above the ACGIH BEI for $\mathrm{Cr}$ and no sample was above the DFG EKA for V and Ni (Table 3).

Results of biological monitoring of urinary metals in Tunisia are available only for $\mathrm{Pb}$. The levels of $\mathrm{Pb}$ found in study workers were much lower than those in a small control group of 20 individuals ( 5.0 vs. $38 \mu \mathrm{g} / \mathrm{L}$ ), but it should be noted that the reported values were surprisingly high [29]. The metals levels were then compared with the reference values for the Italian general population provided by the Italian Society of Reference Values (SIVR) [30], and with the DFG BAR (Table 3). From 3.4\% (Co) to 72\% $(\mathrm{Pb})$ of samples were above the reference values for the Italian population. In particular, 63, 19, 14, and $69 \%$ of samples were above the reference values for $\mathrm{Cr}, \mathrm{Ni}$, $\mathrm{As}$, and $\mathrm{Cd}$, respectively. In comparison with the BAR values, from $7(\mathrm{Co})$ to $73 \%(\mathrm{Cd})$ of samples were above the BAR values for $\mathrm{Co}, \mathrm{Ba}, \mathrm{Ni}, \mathrm{Cr}$, and $\mathrm{Cd}$ (Table 3).

Overall, these results show that the study workers were occupationally exposed to metals, but the exposure was within biological limit values for most metals. Only for Cd, up to $13.5 \%$ of workers exceeded the biological limit values, in particular the limit proposed by ECHA. 
Table 3. Occupational limit values and reference values for the general population for urinary metals proposed by different organizations. The percentage of samples of study workers exceeding the biological values is shown.

\begin{tabular}{|c|c|c|c|c|c|c|c|}
\hline Metal & Biomarker & Organization & Sampling Time & Biological Value & \multicolumn{2}{|c|}{ Value } & $\begin{array}{l}\text { \% of Samples Above the } \\
\text { Biological Value }\end{array}$ \\
\hline \multirow{5}{*}{$\begin{array}{l}\text { Vanadium and its inorganic } \\
\text { compounds including vanadium } \\
\text { pentaoxide }\end{array}$} & \multirow{5}{*}{ urinary $\mathrm{V}$} & \multirow{4}{*}{ DFG } & \multirow{4}{*}{$\begin{array}{l}\text { End of exposure, for long-term } \\
\text { exposures: at the end of the shift } \\
\text { after several shifts }\end{array}$} & \multirow{4}{*}{ EKA } & $\operatorname{Air}\left(\mathrm{mg} / \mathrm{m}^{3}\right)$ & $\begin{array}{l}\text { Biomarker }(\mu \mathrm{g} / \mathrm{g} \\
\text { creatinine) }\end{array}$ & \\
\hline & & & & & 0.025 & 35 & 0 \\
\hline & & & & & 0.050 & 70 & 0 \\
\hline & & & & & 0.100 & 140 & 0 \\
\hline & & SIVR & - & SIVR & 0.025 & $55 \mu \mathrm{g} / \mathrm{L}$ & 48 \\
\hline \multirow{2}{*}{ Chromium (VI), water soluble fume } & \multirow{4}{*}{ urinary $\mathrm{Cr}$} & \multirow{2}{*}{ ACGIH } & End of shift at end of workweek & BEI & \multicolumn{2}{|c|}{$25 \mu \mathrm{g} / \mathrm{L}$} & 0 \\
\hline & & & Increase during shift & BEI & \multicolumn{2}{|c|}{$10 \mu \mathrm{g} / \mathrm{L}$} & 2 \\
\hline \multirow{2}{*}{ Chromium and its compounds } & & DFG & End of shift & BAR & \multicolumn{2}{|c|}{$0.6 \mu \mathrm{g} / \mathrm{L}$} & 63 \\
\hline & & SIVR & - & SIVR & \multicolumn{2}{|c|}{$0.050-0.60 \mu \mathrm{g} / \mathrm{L}$} & 63 \\
\hline Manganese & urinary $\mathrm{Mn}$ & SIVR & - & SIVR & \multicolumn{2}{|c|}{$0.040-1.5 \mu \mathrm{g} / \mathrm{L}$} & 15 \\
\hline \multirow{10}{*}{ Cobalt and its compounds } & \multirow{10}{*}{ urinary Co } & ACGIH & End of shift at end of workweek & BEI & \multicolumn{2}{|c|}{$15 \mu \mathrm{g} / \mathrm{L}$} & 1 \\
\hline & & \multirow{8}{*}{ DFG } & \multirow{8}{*}{$\begin{array}{l}\text { End of exposure, for long term } \\
\text { exposure }\end{array}$} & \multirow{6}{*}{ EKA } & Air $\left(\mathrm{mg} / \mathrm{m}^{3}\right)$ & Biomarker $(\mu \mathrm{g} / \mathrm{L})$ & \\
\hline & & & & & 0.010 & 6 & 0 \\
\hline & & & & & 0.025 & 15 & 0 \\
\hline & & & & & 0.050 & 30 & 1 \\
\hline & & & & & 0.100 & 60 & 0 \\
\hline & & & & & 0.500 & 300 & 0 \\
\hline & & & & BLW & \multicolumn{2}{|c|}{35} & 0 \\
\hline & & & & BAR & \multicolumn{2}{|c|}{1.5} & 7 \\
\hline & & SIVR & - & SIVR & \multicolumn{2}{|c|}{$0.077-2.2$} & 3 \\
\hline \multirow{4}{*}{$\begin{array}{l}\text { Nickel (nickel metal, oxide, } \\
\text { carbonate, sulfide, sulfidic ores) }\end{array}$} & \multirow{6}{*}{ urinary $\mathrm{Ni}$} & & \multirow{4}{*}{$\begin{array}{l}\text { For long-term exposures: at the } \\
\text { end of the shift after several shifts }\end{array}$} & \multirow{4}{*}{ EKA } & $\operatorname{Air}\left(\mathrm{mg} / \mathrm{m}^{3}\right)$ & Biomarker $(\mu \mathrm{g} / \mathrm{L})$ & \\
\hline & & & & & 0.10 & 15 & 0 \\
\hline & & DFG & & & 0.30 & 30 & 0 \\
\hline & & & & & 0.50 & 45 & 0 \\
\hline \multirow[t]{2}{*}{ Nickel and its compounds } & & & $\begin{array}{l}\text { For long-term exposures: at the } \\
\text { end of the shift after several shifts }\end{array}$ & BAR & \multicolumn{2}{|c|}{$3 \mu \mathrm{g} / \mathrm{L}$} & 42 \\
\hline & & SIVR & - & SIVR & \multicolumn{2}{|c|}{$0.372-4.44 \mu \mathrm{g} / \mathrm{L}$} & 19 \\
\hline
\end{tabular}


Table 3. Cont

\begin{tabular}{|c|c|c|c|c|c|c|}
\hline Metal & Biomarker & Organization & Sampling Time & Biological Value & Value & $\begin{array}{c}\text { \% of Samples Above the } \\
\text { Biological Value }\end{array}$ \\
\hline \multirow{3}{*}{ Copper and its inorganic compounds } & \multirow{3}{*}{ urinary $\mathrm{Cu}$} & \multirow{2}{*}{ DFG } & - & BAT & NA & \\
\hline & & & - & BAR & $\mathrm{NA}$ & \\
\hline & & SIVR & - & SIVR & $5.01-24.0 \mu \mathrm{g} / \mathrm{L}$ & 52 \\
\hline Zinc & urinary $\mathrm{Zn}$ & SIVR & - & LVR & ND-1048 $\mu \mathrm{g} / \mathrm{L}$ & 40 \\
\hline \multirow{5}{*}{$\begin{array}{l}\text { Cadmium and its inorganic } \\
\text { compounds }\end{array}$} & \multirow{5}{*}{ urinary $\mathrm{Cd}$} & ACGIH & Not critical & BEI & $5 \mu \mathrm{g} / \mathrm{g}$ creatinine & 3 \\
\hline & & ECHA & Not critical & BLV & $2 \mu \mathrm{g} / \mathrm{g}$ creatinine & 14 \\
\hline & & \multirow{2}{*}{ DFG } & Not fixed & BLW & NA & \\
\hline & & & Not fixed & BAR (NS) & $0.8 \mu \mathrm{g} / \mathrm{L}$ & 73 \\
\hline & & SIVR & - & SIVR & $0.100-0.900 \mu \mathrm{g} / \mathrm{L}$ & 69 \\
\hline \multirow[t]{2}{*}{ Barium compounds, soluble } & \multirow[t]{2}{*}{ urinary $\mathbf{B a}$} & DFG & $\begin{array}{l}\text { End of shift/ for long-term } \\
\text { exposures: at the end of the shift } \\
\text { after several shifts }\end{array}$ & BAR & $10 \mu \mathrm{g} / \mathrm{L}$ & 14 \\
\hline & & SIVR & - & LVR & ND-6.97 $\mu \mathrm{g} / \mathrm{L}$ & 24 \\
\hline Thallium & urinary $\mathrm{Tl}$ & SIVR & - & SIVR & $0.0600-0.759 \mu \mathrm{g} / \mathrm{L}$ & 15 \\
\hline Lead & urinary $\mathrm{Pb}$ & SIVR & - & SIVR & $1.170-2.94 \mu \mathrm{g} / \mathrm{L}$ & 72 \\
\hline
\end{tabular}

ACGIH = American Conference for Governmental industrial Hygiene; DFG = German Research Association (Deutsche Forschung Gemeinschaft); ECHA = European Chemicals Agency;

SIVR = Italian Society for Reference Value. BAR = biological reference values for workplace substances; BAT = biological tolerance values (Biologische Arbeitsstoff-Toleranzwerte);

$\mathrm{BEI}=$ Biological Exposure Index; BLV = biological limit values; BLW = biological guidance value (Biologische Leit-Werte); EKA = exposure equivalents for carcinogenic substances

(Expositionsäquivalente für krebserzeugende Arbeitsstoffe); $\mathrm{LVR}=$ literature reference value; $\mathrm{ND}=$ not determined; $\mathrm{NS}=$ nonsmokers; $\mathrm{NA}=$ insufficient data for the derivation of a value. 
Table 4 shows a comparison with previous studies where biological monitoring of steel workers has been performed using urinary metals as biomarkers of exposure. The comparison with previous studies is difficult because of the variability of the production process between foundries and the lack of process description in many studies. Moreover, most studies investigated a limited numbers of metals, mostly Ni, Cd, and Cr, while spurious studies were found for the other metals (Table 4). The levels of $\mathrm{Ni}, \mathrm{Cd}, \mathrm{Cr}, \mathrm{Pb}$, and $\mathrm{Cu}$ were 2-5 fold higher than levels found in other steel foundries [6-8,13], or in a copper foundry [9]. Levels of $\mathrm{Zn}$ were two fold higher than those reported by the only study reporting urinary $\mathrm{Zn}$ in steel foundry workers [6].

For As, it is worth to highlight that we measured total arsenic in urine (that is the sum of inorganic and organic As), while other studies measured inorganic arsenic $[6,8,9]$. This is the reason why in this study $2-5$ fold higher As levels were found. Arsenic can be found in considerable amount in food and drinking water: a daily intake of total As from food and beverages is generally in the range of 20-300 $\mu \mathrm{g} /$ day [31]. However, the arsenic in food is mainly associated with the presence of arsenobetaine and arsenocholine that are considered non-toxic [31,32]. Regional differences are seen in the daily intake of total arsenic through food, mainly attributable to the type and the quantity of food consumed. In particular, seafood is known to give a major contribution to the ingestion of arsenic [32]. As the investigated plant is located in the Northern Tunisia, close to the Mediterranean Sea, it is probable that seafood is a relevant contributor to the diet of the investigated individuals. Unfortunately, this cannot be verified, as data about worker's diet were not collected.

Levels of Mn were comparable to those found in an integrated steel foundry [6] and in a non-ferrous metal smelting plant [7], but four-fold lower than those from a steel mill production plant [12]. Levels of $\mathrm{Tl}$ and $\mathrm{Ba}$ were comparable to the only values found in the literature about urinary $\mathrm{Tl}$ [10] and $\mathrm{Ba}$ [6] in steel foundry workers and to that reported for thallium workers [33].

Levels of Co were much lower (8-20 fold) than levels found in foundry workers from a steel mill production plant in Pakistan [12] and a steel plant in Taiwan [11] and comparable to those of an Italian integrated steel foundry [6]. As far as we know, no studies reported $\mathrm{V}$ urinary levels in foundry workers. Levels found in this study were much higher than those reported for welders (median $0.08 \mu \mathrm{g} / \mathrm{g} \mathrm{cr}$ ) [34]. In summary, the comparison with previous studies shows that the levels of $\mathrm{Ni}, \mathrm{Cd}$, $\mathrm{Cr}, \mathrm{Pb}, \mathrm{Cu}$, and $\mathrm{Zn}$ were higher, while the levels of $\mathrm{Mn}, \mathrm{Tl}, \mathrm{Ba}$, and $\mathrm{Co}$ were comparable or lower than those found in other steel foundries.

Considering the different job titles, the SSW had the lowest levels for most metals. One reason of this unexpected result could be the workshop design, which has openings on both the opposite sides. This may favor the ventilation and thus reduce the exposure of these workers. On the contrary, no differences in metal levels were found among the other job titles, which worked in closed departments.

The regression analysis predicting the urinary levels of metals showed that age was a significant determinant for $\mathrm{Co}, \mathrm{Cu}, \mathrm{Zn}, \mathrm{As}, \mathrm{Cd}, \mathrm{Tl}$, and $\mathrm{Pb}$. For $\mathrm{Cd}$ and $\mathrm{Pb}$, this is in agreement with the known tendency for these metals to accumulate in the body [35,36]. Otherwise, the smoking habit was not a determinant factor for any metal. Tobacco smoke is a known significant source of cadmium: it has been estimated that tobacco smokers are exposed to $1.7 \mu \mathrm{g}$ cadmium per cigarette [37]. Notwithstanding the effect of cigarette smoke was expected, we did not find such an association, this may be explained by the high Cd levels reasonably due to occupational exposure. 
Table 4. Literature summary of biological monitoring studies reporting urinary metal levels in foundry workers. The production process and the analytical assay used to quantify metals in urine is also shown.

\begin{tabular}{|c|c|c|c|c|c|c|c|c|c|c|c|c|c|c|}
\hline $\begin{array}{l}\text { Authors, Year } \\
\text { Country }\end{array}$ & $\begin{array}{c}\text { Production Process } \\
\text { (Analytical Method) }\end{array}$ & $\mathbf{N}$ & $\mathrm{V} \mu \mathrm{g} / \mathrm{L}$ & $\mathrm{Cr} \mu \mathrm{g} / \mathrm{L}$ & $\mathrm{Mn} \mu \mathrm{g} / \mathrm{L}$ & Co $\mu \mathrm{g} / \mathrm{L}$ & $\mathrm{Ni} \mu \mathrm{g} / \mathrm{L}$ & $\mathrm{Cu} \mu \mathrm{g} / \mathrm{L}$ & $\mathrm{Zn} \mu \mathrm{g} / \mathrm{L}$ & As $\mu \mathrm{g} / \mathrm{L}$ & $\mathrm{Cd} \mu \mathrm{g} / \mathrm{L}$ & Ва $\mu \mathrm{g} / \mathrm{L}$ & $\mathrm{Tl} \mu \mathrm{g} / \mathrm{L}$ & $\mathrm{Pb} \mu \mathrm{g} / \mathrm{L}$ \\
\hline $\begin{array}{l}\text { This Study, } 2019 \\
\text { Tunisia }\end{array}$ & $\begin{array}{l}\text { Electric steel foundry } \\
\text { (ICP-MS) }\end{array}$ & 89 & $\begin{array}{c}0.85 \\
(0.05-2.40)^{\mathrm{a}} \\
\end{array}$ & $\begin{array}{c}0.75 \\
(0.18-5.51)^{\mathrm{a}} \\
\end{array}$ & $0.6(0.1-4.1)^{a}$ & $0.4(0.1-1.9)^{a}$ & $2.4(0.5-6.3)^{\mathrm{a}}$ & $25(5-54)^{a}$ & $\begin{array}{c}895 \\
(137-3191)^{\text {a }} \\
\end{array}$ & $\begin{array}{c}29(3-156)^{\mathrm{a}} \\
\text { (total As) }^{2}\end{array}$ & $\begin{array}{c}1.43 \\
(0.10-4.57)^{a} \\
\end{array}$ & $\begin{array}{c}3.5 \\
(0.3-17.0)^{\mathrm{a}} \\
\end{array}$ & $\begin{array}{c}0.4 \\
(0.04-1.1)^{\mathrm{a}} \\
\end{array}$ & $\begin{array}{c}5.0 \\
(0.8-19.0)^{\mathrm{a}} \\
\end{array}$ \\
\hline $\begin{array}{l}\text { Apostoli et al., } \\
1988 \text { Italy [10] }\end{array}$ & $\begin{array}{c}\text { Cast iron foundry } \\
\text { cupola furnace (X-ray } \\
\text { fluorescence } \\
\text { spectrometry) } \\
\end{array}$ & 21 & - & & & & & & & & & & $\begin{array}{c}0.33 \\
(0.06-1.04)^{\mathrm{b}}\end{array}$ & \\
\hline $\begin{array}{l}\text { Horng et al., } 2003 \\
\text { Taiwan [11] }\end{array}$ & $\begin{array}{l}\text { Steel production plant } \\
\text { (Differential pulse } \\
\text { Stripping } \\
\text { voltammetry) }\end{array}$ & 63 & - & - & - & $\begin{array}{c}8.18 \\
(3.06-23.30){ }^{b}\end{array}$ & $\begin{array}{c}33.10 \\
(13.90-78.90) \\
\mathrm{b} .\end{array}$ & - & - & - & $\begin{array}{c}9.52 \\
(3.19-22.07) \\
\mathrm{b}\end{array}$ & - & - & $\begin{array}{c}53.50 \\
(28.90-85.60) \\
\mathrm{b}\end{array}$ \\
\hline $\begin{array}{c}\text { Afridi et al., } 2009 \\
\text { Pakistan [12] }\end{array}$ & $\begin{array}{l}\text { Steel mill Production } \\
\text { (GFAAS) }\end{array}$ & 56 & - & - & $2.49 \pm 0.7^{\mathrm{c}}$ & $3.56 \pm 0.6^{\mathrm{c}}$ & - & $\begin{array}{c}530 \pm 5^{\mathrm{c}} \\
\mathrm{mg} / \mathrm{L}\end{array}$ & - & $7.9 \pm 1.8^{\mathrm{c}}$ & - & - & - & - \\
\hline $\begin{array}{l}\text { De Palma et al., } \\
2012 \text { Italy [8] }\end{array}$ & $\begin{array}{l}\text { Electric steel foundry } \\
\text { (ICP-MS and AAS) }\end{array}$ & 339 & - & $\begin{array}{c}0.44 \\
(0.06-1.80)^{a}\end{array}$ & - & - & $\begin{array}{c}0.90 \\
(0.10-3.39)^{\mathrm{a}}\end{array}$ & - & - & $\begin{array}{c}6.40 \\
(0.50-16.08) \\
\text { a, (inorganic } \\
\text { As) } \\
\end{array}$ & $\begin{array}{c}0.28 \\
(0.13-0.83)^{\mathrm{a}}\end{array}$ & - & - & - \\
\hline $\begin{array}{l}\text { Soleo et al., } 2012 \\
\text { Italy [6] }\end{array}$ & $\begin{array}{l}\text { Integrated-cycle steel } \\
\text { foundry (ICP-MS and } \\
\text { AAS) }\end{array}$ & 49 & - & $\begin{array}{c}0.10< \\
0.10-0.40)^{\mathrm{d}}\end{array}$ & $\begin{array}{c}0.40 \\
(0.00-1.80)^{\mathrm{d}}\end{array}$ & $\begin{array}{c}0.50 \\
(0.08-1.20)^{\mathrm{d}}\end{array}$ & $\begin{array}{c}0.60 \\
(0.20-3.00)^{\mathrm{d}}\end{array}$ & $\begin{array}{c}16.0 \\
(3.3-51.0)^{\mathrm{d}}\end{array}$ & $\begin{array}{c}352 \\
\underset{(67.0-2626.0)}{\mathrm{d}}\end{array}$ & $\begin{array}{c}5.0 \\
(0.5-75.0) \mathrm{d} \\
\text { (inorganic } \\
\text { As) } \\
\end{array}$ & $\begin{array}{c}0.40 \\
(<0.006-1.40) \\
\mathrm{d}\end{array}$ & $\begin{array}{c}2.60 \\
\underset{(0.20-12.00)}{\mathrm{d}}\end{array}$ & - & $\begin{array}{c}1.50 \\
(0.20-9.20)^{\mathrm{d}}\end{array}$ \\
\hline $\begin{array}{l}\text { Ściskalska et al., } \\
2014 \text { Poland [9] }\end{array}$ & Copper foundry (AAS) & 352 & - & & & & & & & $\begin{array}{c}\mathrm{S}^{\mathrm{a}}: 12.76 \\
{ }^{\mathrm{e} *} \mathrm{NS}^{\mathrm{a}}: 13.0 \\
\text { e* } \\
\text { (inorganic } \\
\text { As) }\end{array}$ & $\begin{array}{l}S^{\mathrm{a}}: 0.83 \\
{ }^{\mathrm{e} *} \mathrm{NS}^{\mathrm{a}}: 0.56 \\
\mathrm{e} *\end{array}$ & & & \\
\hline $\begin{array}{l}\text { dos Santos et al., } \\
2015 \text { Brasil [7] }\end{array}$ & $\begin{array}{c}\text { Nonferrous metal } \\
\text { foundries (GFAAS) }\end{array}$ & 178 & - & - & $0.64(5.64)^{\mathrm{f}}$ & - & $1.8(3.15)^{\mathrm{f}}$ & - & - & - & $1.27(4.39)^{\mathrm{f}}$ & - & - & - \\
\hline $\begin{array}{l}\text { Wang et al., } 2019 \\
\quad \text { China [13] }\end{array}$ & $\begin{array}{l}\text { Steel smelting plant } \\
\text { (AAS) }\end{array}$ & 162 & - & - & - & - & $\begin{array}{c}1.18^{*} \\
(0.005-4.40)^{\mathrm{d}}\end{array}$ & $\begin{array}{c}6.44^{*} \\
\underset{\mathrm{d}}{0.0045-17.80)}\end{array}$ & & & $\begin{array}{c}0.93^{*} \\
(0.17-3.15)^{\mathrm{d}}\end{array}$ & & & $\begin{array}{c}0.025 * \\
(0.025-1.84) \\
\text { d }\end{array}$ \\
\hline
\end{tabular}

$\mathrm{N}=$ number of samples; ICP-MS: Inductively coupled plasma-mass spectrometer; GF-AAS: Graphite furnace atomic absorption spectroscopy; $=$ smokers; NS = nonsmokers; ${ }^{\mathrm{a}}=$ median

$\left(5\right.$ th-95th) ${ }^{b}=$ mean $($ range $) ;{ }^{\mathrm{c}}=$ mean $\pm \mathrm{DS} ;{ }^{\mathrm{d}}=$ median $\left(\right.$ range) ${ }^{\mathrm{e}}=$ mean; ${ }^{\mathrm{f}}=$ geometric mean $(\mathrm{GSD}){ }^{*} \mu \mathrm{g} / \mathrm{g}$ creatinine. 
In a previous study, we evaluated 8-oxodG levels, used as a marker of oxidative damage, and its association with PAH exposure [19]. Results showed that 8-oxodG levels were in the range of the general population for healthy Italian individuals (5th-95th percentile: $1.75-10.2 \mu \mathrm{g} / \mathrm{g}$ creatinine) [38]. Moreover, although urinary PAHs were associated to 8-oxodG, they were only minor contributors to 8-oxodG excretion [19]. That finding made us to suppose that 8-oxodG was possibly affected by the metal exposure and then to study the co-exposure to metals and PAHs and the possible additive effect on 8-oxodG excretion. In this study, positive correlations between most of the investigated urinary metals ( $\mathrm{Mn}, \mathrm{Tl}, \mathrm{Zn}, \mathrm{As}, \mathrm{Pb}, \mathrm{Co}, \mathrm{Ba}, \mathrm{Cr}$, and $\mathrm{Cd}$ ) and 8-oxodG were found, with Pearson's $r$ in the 0.194-0.345 range. The multiple regression model, studying the association between 8-oxodG and urinary metals and corrected for confounding factors (model A), confirmed the positive association for all metals, but for $\mathrm{Cr}$ and $\mathrm{Cd}$. However, the variance explained by this model was low (3-12\%), showing that metal exposure was not the major contributor to 8-oxodG (Table 2). This result is partially in accordance to what previously reported for coke-oven workers in China, showing that As and $\mathrm{Ni}$ were weak predictors of 8-oxodG, while no association was found for $\mathrm{Cd}, \mathrm{Cr}$, and $\mathrm{Pb}[39] . \mathrm{Pb}$ and $\mathrm{Cd}$ resulted significant predictor of 8-oxodG also in steel-iron mining and smelting workers in China, while no association was found for $\mathrm{Cu}$ and $\mathrm{Ni}$ [13]. Studying the association between 8-oxodG and the co-exposure to metals and PAHs corrected by confounding factors (model B), positive associations were found for the same metals, with the exception of $\mathrm{Co}$, and U-PHE was a positive significant predictor too. The variances explained by model B (11-17\%) were higher than model A, suggesting that the co-exposure to metals and PAHs enhances 8-oxodG excretion (Table 2). Similar findings showed an additive interaction effect of $\mathrm{As}, \mathrm{Cd}, \mathrm{Cr}, \mathrm{Ni}, \mathrm{Pb}$, and $\mathrm{PAH}$ co-exposure on 8-oxodG excretion in coke oven workers [39], while a study among traffic conductors found an additive effect of co-exposure to $\mathrm{Cd}$ and $\mathrm{PAH}$ (but not $\mathrm{Ni}, \mathrm{As}$, and $\mathrm{Pb}$ ) on 8-oxodG [40]. Overall, our results, together with previous studies, seem to point to the existence of an addictive interaction between metal and PAH exposure on 8-oxodG levels, even if this effect is weak and involving different metals. Discrepancies among studies may depend on differences in both PAH and metal exposure levels. The variance explained by models remains low (up to 17\%) suggesting that higher doses of PAHs and/or metals are required to induce oxidative damage to DNA. Moreover, the comparison of the relative contribution of each metal and PAH exposure on 8-oxodG, show a major role played by U-PHE, with 8-oxodG increase due mainly to U-PHE than to metals.

\section{Conclusions}

In conclusion, the comparison with existing occupational limit values and with reference value for the general population shows that the study workers were occupationally exposed to metals, but the their exposure was within the biological limit values for most metals. The multiple regression models studying the association between 8-oxodG and the co-exposure to metals and PAHs explained only a minor part of the observed variance. This indicates that neither the exposure to metals nor the co-exposure to metals and PAHs are major determinants of 8-oxodG excretion.

Author Contributions: Conceptualization, L.C., M.H., and S.F.; methodology, L.C., M.H., D.C.; validation, L.C., S.S., E.P., L.O.; formal analysis, L.C., S.S., E.P., L.O.; investigation, L.C., M.H.; resources, D.S.-M., S.F.; data curation, D.C., L.C., M.H., writing-original draft preparation, L.C., M.H.; writing-review and editing, L.C., M.H., S.F.; visualization, L.C.; supervision, L.C., S.F.; project administration, L.C., S.F.; funding acquisition, D.S.-M., S.F. All authors have read and agreed to the published version of the manuscript.

Funding: The authors of this study did not receive external funds. M.H. received a PhD fellowship from the Tunisian Ministry of Higher Education and Scientific Research and the University of Monastir.

Acknowledgments: We are indebted to the administration of the electric steel foundry for facilitating the access to the plant, to the plant medical staff for their help in the sample collection, and to the workers who volunteered for the study.

Conflicts of Interest: The authors declare no conflict of interest. 


\section{References}

1. Remus, R.; Aguado Monsonet, A.; Roudier, S.; Delgado Sancho, L. Best Available Techniques (BAT) Reference Document for Iron and Steel Production; European Union, Joint Research Center: Seville, Spain, 2013.

2. IARC. A Review of Human Carcinogens. Chemical Agents and Related Occupations. IARC Monographs on the Evaluation of Carcinogenic Risks to Humans; International Agency for Research on Cancer (IARC): Lyon, France, 2012; Volume 100F.

3. Rota, M.; Bosetti, C.; Boccia, S.; Boffetta, P.; La Vecchia, C. Occupational exposures to polycyclic aromatic hydrocarbons and respiratory and urinary tract cancers: An updated systematic review and a meta-analysis to 2014. Arch. Toxicol. 2014, 88, 1479-1490. [CrossRef]

4. Westberg, H.; Andersson, L.; Bryngelsson, I.L.; Ngo, Y.; Ohlson, C.G. Cancer morbidity and quartz exposure in Swedish iron foundries. Int. Arch. Occup. Environ. Health 2013, 86, 499-507. [CrossRef]

5. Cappelletti, R.; Ceppi, M.; Claudatus, J.; Gennaro, V. Health status of male steel workers at an electric arc furnace (EAF) in Trentino, Italy. J. Occup. Med. Toxicol. 2016, 11, 7. [CrossRef]

6. Soleo, L.; Lovreglio, P.; Panuzzo, L.; D’Errico, M.N.; Basso, A.; Gilberti, M.E.; Drago, I.; Tomasi, C.; Apostoli, P. Health risk assessment of exposure to metals in the workers of the steel foundry and in the general population of Taranto (Italy). G. Ital. Med. Lav Ergon. 2012, 34, 381-391. [PubMed]

7. Dos Santos, C.R.; da Silva, C.S.; Nascimento, E.S. Assessment of exposure to cadmium, lead, manganese, and nickel in workers from foundries. Toxicol. Ind. Health 2016, 32, 1784-1790. [CrossRef] [PubMed]

8. De Palma, G.; Corsini, A.; Gilberti, E.; Gabusi, V.; Tagliani, G.; Tomasi, C.; Gandellini, A.; Apostoli, P. Biological monitoring of exposure to carcinogenic metallic elements and polycyclic aromatic hydrocarbons in four secondary metallurgical sectors. G. Ital. Med. Lav. Ergon. 2012, 34, 44-47. [PubMed]

9. Sciskalska, M.; Zalewska, M.; Grzelak, A.; Milnerowicz, H. The influence of the occupational exposure to heavy metals and tobacco smoke on the selected oxidative stress markers in smelters. Biol. Trace Elem. Res. 2014, 159, 59-68. [CrossRef] [PubMed]

10. Apostoli, P.; Maranelli, G.; Minoia, C.; Massola, A.; Baldi, C.; Marchiori, L. Urinary thallium: Critical problems, reference values and preliminary results of an investigation in workers with suspected industrial exposure. Sci. Total Environ. 1988, 71, 513-518. [CrossRef]

11. Horng, C.J.; Horng, P.H.; Hsu, J.W.; Tsai, J.L. Simultaneous determination of urinary cadmium, cobalt, lead, and nickel concentrations in steel production workers by differential pulse stripping voltammetry. Arch. Environ. Health 2003, 58, 104-110. [CrossRef]

12. Afridi, H.I.; Kazi, T.G.; Kazi, N.G.; Jamali, M.K.; Arain, M.B.; Sirajuddin; Kandhro, G.A.; Shah, A.Q.; Baig, J.A. Evaluation of arsenic, cobalt, copper and manganese in biological Samples of Steel mill workers by electrothermal atomic absorption Spectrometry. Toxicol. Ind. Health 2009, 25, 59-69. [CrossRef]

13. Wang, X.; Jin, P.; Zhou, Q.; Liu, S.; Wang, F.; Xi, S. Metal Biomonitoring and Comparative Assessment in Urine of Workers in Lead-Zinc and Steel-Iron Mining and Smelting. Biol. Trace Elem. Res. 2019, 189, 1-9. [CrossRef] [PubMed]

14. Caito, S.; Aschner, M. Neurotoxicity of metals. Handb. Clin. Neurol. 2015, 131, 169-189. [CrossRef] [PubMed]

15. Solenkova, N.V.; Newman, J.D.; Berger, J.S.; Thurston, G.; Hochman, J.S.; Lamas, G.A. Metal pollutants and cardiovascular disease: Mechanisms and consequences of exposure. Am. Heart J. 2014, 168, 812-822. [CrossRef] [PubMed]

16. Nordberg, G.F.; Fowler, B.A.; Nordberg, M. Handbook on the Toxicology of Metals, 4th ed.; Nordberg, G.F., Fowler, B.A., Nordberg, M., Eds.; Academic Press: Cambridge, MA, USA, 2015.

17. Pilger, A.; Rüdiger, H.W. 8-Hydroxy-2'-deoxyguanosine as a marker of oxidative DNA damage related to occupational and environmental exposures. Int. Arch. Occup. Environ. Health 2006, 80, 1-15. [CrossRef] [PubMed]

18. Floyd, R.A.; Watson, J.J.; Wong, P.K.; Altmiller, D.H.; Rickard, R.C. Hydroxyl free radical adduct of deoxyguanosine: Sensitive detection and mechanisms of formation. Free Radic. Res. Commun. 1986, 1, 163-172. [CrossRef] [PubMed]

19. Hanchi, M.; Campo, L.; Polledri, E.; Olgiati, L.; Consonni, D.; Saidane-Mosbahi, D.; Fustinoni, S. Urinary 8-Oxo-7,8-Dihydro-2'-Deoxyguanosine in Tunisian Electric Steel Foundry Workers Exposed to Polycyclic Aromatic Hydrocarbons. Ann. Work Expo. Health 2017, 61, 333-343. [CrossRef] 
20. Campo, L.; Hanchi, M.; Olgiati, L.; Polledri, E.; Consonni, D.; Zrafi, I.; Saidane-Mosbahi, D.; Fustinoni, S. Biological Monitoring of Occupational Exposure to Polycyclic Aromatic Hydrocarbons at an Electric Steel Foundry in Tunisia. Ann. Occup. Hyg. 2016, 60, 700-716. [CrossRef]

21. Campo, L.; Fustinoni, S.; Bertazzi, P. Quantification of carcinogenic 4- to 6-ring polycyclic aromatic hydrocarbons in human urine by solid-phase microextraction gas chromatography-isotope dilution mass spectrometry. Anal. Bioanal. Chem. 2011, 401, 625-634. [CrossRef]

22. Fustinoni, S.; Campo, L.; Polledri, E.; Mercadante, R.; Erspamer, L.; Ranzi, A.; Lauriola, P.; Goldoni, C.A.; Bertazzi, P. A validated method for urinary cotinine quantification used to classify active and environmental tobacco smoke exposure. Curr. Anal. Chem. 2013, 9, 447-456. [CrossRef]

23. Campo, L.; Polledri, E.; Bechtold, P.; Gatti, G.; Ranzi, A.; Lauriola, P.; Goldoni, C.A.; Bertazzi, P.A.; Fustinoni, S. Determinants of active and environmental exposure to tobacco smoke and upper reference value of urinary cotinine in not exposed individuals. Environ. Res. 2016, 148, 154-163. [CrossRef]

24. Kroll, M.H.; Chester, R.; Hagengruber, C.; Blank, D.W.; Kestner, J.; Rawe, M. Automated determination of urinary creatinine without sample diluition: Theory and practice. Clin. Chem. 1986, 32, 446-452. [CrossRef] [PubMed]

25. ACGIH. TLVs and BEIs Based on the Documentation of the Threshold Limit Values for Chemical Substances and Physical Agents and Biological Indices; American Conference of Governmental Industrial Hygienists (ACGIH): Cincinnati, OH, USA, 2017.

26. DFG. List of MAK and BAT Values 2018: Maximum Concentrations and Biological Tolerance Values at the Workplace; Deutsche Forschungsgemeinschaft (DFG): Bonn, Germany, 2018; Volume 54.

27. RAC. Opinion on Scientific Evaluation of Occupational Exposure Limits for Nickel and Its Compounds; Committee for Risk Assessment (RAC) of the European Chemical Agency (ECHA): Helsinki, Finland, 2018.

28. SCOEL. Cadmium and Its Organic Compounds: Opinion from the Scientific Committee on Occupational Exposure Limits-SCOEL/OPIN/336; Scientific Committee on Occupational Exposure Limits (SCOEL) of the European Union: Luxembourg, 2017.

29. Nouioui, M.A.; Araoud, M.; Milliand, M.L.; Bessueille-Barbier, F.; Amira, D.; Ayouni-Derouiche, L.; Hedhili, A. Biomonitoring chronic lead exposure among battery manufacturing workers in Tunisia. Environ. Sci. Pollut. Res. Int. 2019, 26, 7980-7993. [CrossRef] [PubMed]

30. SIVR. Fourth List of Reference Values for Elements, Organic Compounds and Their Metabolites (Quarta Lista dei Valori di Riferimento per Elementi, Composti Organici e Loro Metabolite). Società Italiana Valori di Riferimento (SIVR): 2017. Available online: www.valoridiriferimento.it (accessed on 20 December 2017).

31. Fowler, B.A.; Chou, C.-H.S.J.; Jones, R.L.; Sullivan, D.W.J.; Chen, C.-J. Arsenic. In Handbook on the Toxicology of Metals, 4th ed.; Nordberg, G.F., Fowler, B.A., Nordberg, M., Eds.; Academic Press: Cambridge, MA, USA, 2014; Volume II.

32. Soleo, L.; Lovreglio, P.; Iavicoli, S.; Antelmi, A.; Drago, I.; Basso, A.; Di Lorenzo, L.; Gilberti, M.E.; De Palma, G.; Apostoli, P. Significance of urinary arsenic speciation in assessment of seafood ingestion as the main source of organic and inorganic arsenic in a population resident near a coastal area. Chemosphere 2008, 73, 291-299. [CrossRef]

33. Staff, J.F.; Cotton, R.J.; Warren, N.D.; Morton, J. Comparison of urinary thallium levels in non-occupationally exposed people and workers. Int. Arch. Occup. Environ. Health 2014, 87, 275-284. [CrossRef]

34. Ellingsen, D.G.; Chashchin, M.; Berlinger, B.; Fedorov, V.; Chashchin, V.; Thomassen, Y. Biological monitoring of welders' exposure to chromium, molybdenum, tungsten and vanadium. J. Trace Elem. Med. Biol. 2017, 41, 99-106. [CrossRef] [PubMed]

35. Nordberg, G.F.; Nogawa, K.; Nordberg, M. Cadmium. In Handbook on the Toxicology of Metals, 4th ed.; Nordberg, G.F., Fowler, B.A., Nordberg, M., Eds.; Academic Press: Cambridge, MA, USA, 2015; Volume II.

36. Skerfving, S.; Bergdahl, I.A. Lead. In Handbook on the Toxicology of Metals, 4th ed.; Nordberg, G.F., Fowler, B.A., Nordberg, M., Eds.; Academic Press: Cambridge, MA, USA, 2015; Volume II.

37. Elinder, C.G.; Kjellström, T.; Lind, B.; Linnman, L.; Piscator, M.; Sundstedt, K. Cadmium exposure from smoking cigarettes: Variations with time and country where purchased. Environ. Res. 1983, 32, 220-227. [CrossRef] 
38. Andreoli, R.; Manini, P.; De Palma, G.; Alinovi, R.; Goldoni, M.; Niessen, W.M.; Mutti, A. Quantitative determination of urinary 8-oxo-7,8-dihydro-2'-deoxyguanosine, 8-oxo-7,8-dihydroguanine, 8-oxo-7,8-dihydroguanosine, and their non-oxidized forms: Daily concentration profile in healthy volunteers. Biomarkers 2010, 15, 221-231. [CrossRef]

39. Wang, T.; Feng, W.; Kuang, D.; Deng, Q.; Zhang, W.; Wang, S.; He, M.; Zhang, X.; Wu, T.; Guo, H. The effects of heavy metals and their interactions with polycyclic aromatic hydrocarbons on the oxidative stress among coke-oven workers. Environ. Res. 2015, 140, 405-413. [CrossRef]

40. Huang, H.B.; Chen, G.W.; Wang, C.J.; Lin, Y.Y.; Liou, S.H.; Lai, C.H.; Wang, S.L. Exposure to heavy metals and polycyclic aromatic hydrocarbons and DNA damage in Taiwanese traffic conductors. Cancer Epidemiol. Biomark. Prev. 2013, 22, 102-108. [CrossRef]

(C) 2020 by the authors. Licensee MDPI, Basel, Switzerland. This article is an open access article distributed under the terms and conditions of the Creative Commons Attribution (CC BY) license (http://creativecommons.org/licenses/by/4.0/). 